\title{
Understanding the Value of Vocational Education and Training Institutions: Technical Division
}

\author{
Elkanah Olumide, Aiyewalehinmi \\ Department of Civil Engineering, the Federal University of Technology, Akure
}

\begin{abstract}
Polytechnics, colleges of technologies, technical training institutes, nursing colleges, research laboratories centre of excellence, distance learning centre, including universities are major providers of vocational education and training (VET) in Nigeria. They form a network of institution that supports the production of higher -order capacity necessary for the development of our nation - Nigeria. This paper addresses the complex set of factors which should be considered when assessing the role and performance of vocational education and training institutions (VET) in Nigeria. It looks at the economic, social and political context and examines the major trend of insignificance for VET planning.
\end{abstract}

Keyword: - VET, Economic, Social, Political, Capacity Building

\section{INTRODUCTION}

Vocational education and training institutions (VET) are more than the capstone of the traditional educational pyramid; it is a critical column supporting a nation development worldwide. They are not only equipping students with high- level skills necessary for labour market, but also provide essential for training professional and expert development, such as teachers, doctors, lawyers, engineers, civil servants, entrepreneurs civil servants, entrepreneurs, scientists, social scientists, Para - professionals, highly skilled, semi- skilled and many more. It is these individuals who develop the capacity and analytical skills that drive local economy, support civil society, teach our children, lead effective governments and make important decisions and judgment that affect our entire nation or society.

At least from the time of Nigeria independence, there has been a wide range of policy initiatives and programs designed to support continued education innovation in Nigeria. As at today, it is said that a considerable attention is being directed toward Nigerian educational system to determine how it can be made more relevant to the pressing needs that confront Nigerian society.

One of the greatest strength of the VET sector is its emphasis on the application of knowledge which is useful for practical solution of problems. For example, at a time of economic downturn, where predictions of future recovery are clouded by such concerns as structural adjustment and lagging international competitiveness, the federal and state government cannot afford to ignore the gains which can be derived from appropriate investment in practical and relevant education and training. As indicated earlier, college of technologies, polytechnics and universities are major providers of VET and they are being funded and administered by the federal and state governments. Although universities enjoy self independent but governments play important roles in their affairs.

\section{SOCIAL ASPECT}

The social structure of social partners is a very simple one. They are divided into three groups, The VET, governments and industries or commercial enterprises. VET institutions are divided into two groups: public and private organizations. All these organizations receive government funds to conduct their services except private providers such as commercial and business colleges that are not qualified to receive support from both federal and state government including the Federal Capital territory (FCT). Their basic aim was to supplement the existing training.

Governments: in this category form three groups; federal, state and FCT. The distinction between is as old as industrial revolutions. These groups provide funds and management to support VET throughout Nigeria. In year $2000-2006$, both federal and state including FCT spent more than 30 billion on education and some undeclared funds such as IGR were also raised by VET institutions.

Industries: there are two groups namely public and private including other employment organizations, these organizations are described as employers and they are key providers and source for those undertaking contracts training such as apprentice or upgrade their vocational/ professional skills their common interest is to develop knowledge, moral values and understanding required in works of life. 


\section{COMMON INTEREST}

The promotion of knowledge, moral values and understanding in the vocational education and training institutions in Nigeria, allows all parties involved to think in the same directions. The actual technological/ structural and economic framework in which individual social party member operates influence their decisions which do favour each individual member. This frame work provides essential opportunities to both young and adult persons to develop an understanding of the traditions and idea influencing communities in which they live. In addition, to acquire skills that is basic to learning and development. Above all, they are more concerned with development of a systematic instruction that are acceptable to both classrooms and field of practice.

\section{RELATIONSHIPS}

The relationship between VET and its social partners is much more complex and somehow confusing due to regulatory demand or new legislation and shift in environmental and labour values. The words; employee, employer, government agents and industry are interwoven. By definition, industrial and commercial sector can be described as employers of private sector while federal; states, FCT and local government are described as employer's public sector. The only difference between government (public sector and industrial / entrepreneur or commercial sector (private sector) is regulatory demand and new legislation.

The relationship between government and it employees is an important as private sector and its employees. The level of problems in individual organizations tends to be a reliable indicator of its security and status in this environment. The main priority of individual in employment gives him or her security and status in the community in which they live. Operatives desires for security are commonly associated with reluctant to face uncertainty which particularly hard to discharge even where there are opportunities to find employments.

VET is defined as a provider of education and training (life training). VET is divided into public and private, committed to train both young men and women towards the needs of their country and community in order to share common knowledge, awareness and develop their potentials through learning. Vocational education training institutions in Nigeria can also be regarded as a major learning industry and has contributed enormously to both federal and state government economic developments, particularly towards the end of nineteenth and early twentieth century. Considering the position of VET in the country's economy today VET plays an important role that cannot be ignored especially with regard to national workforce which is highly and flexibly skilled that can be associated with productivity and efficiency.

Employment and education policy often mixed but there is fairly a distinction between mind and soul. VET tends to represent the mind while the government tends to represent the soul. On the other hand, this does not mean that VET only has our mind and government only our soul. Of course mind and soul are together, they work together and they cannot be separated. However, the mind tends to be structured towards analytical, controlled, deliberate, broader activities, calculating and ordering roles in organizations or communities. Whereas, the soul tends to bend towards experiment, vision, flexible, uncontrolled, creative activities, passionate and flexible roles of the organizations or communities.

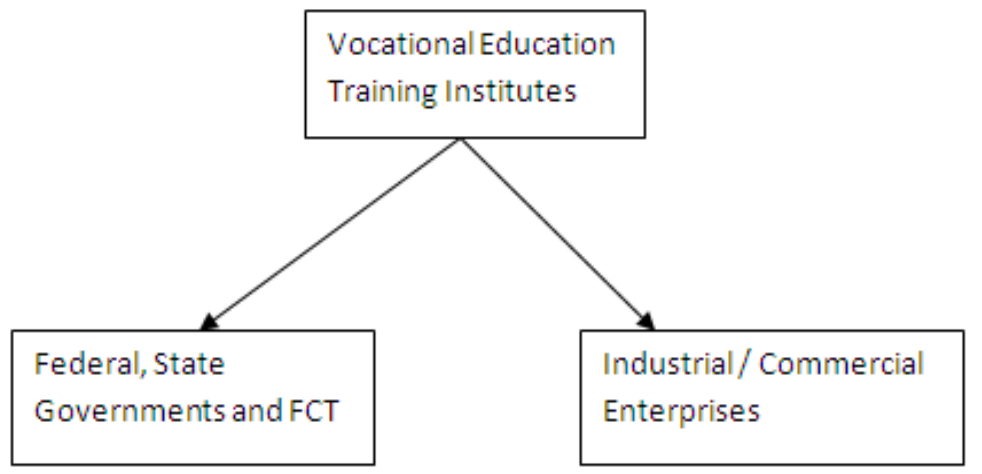

Figure 1: Study model consideration.

\section{VET SOCIAL STRUCTURE /ADMISSION PROCEDURE}

It has not been clear how people combine different forms of related or unrelated information to make judgment or decision about their own interests. The fundamental problem has been whether a person's judgment is derived from the nature of given information, the structure of that information or some interaction of both factors. The admission program shows how people make use of available information to make judgment in the context of educational interest. Dewey (1913) argued that interest should interactive process between an individual and the environment. Interest as viewed as a major motivating force for those who look at students' behaviours in an attempt to determine whether they will achieve their goals or not. Krapp \& Prenzel (1992) 
indicated that educational achievement and satisfaction could be seen as largely the results of the student's ability to make judgments of his or her own interests and right decision about those interests. The development and realization of interest was perceived as an ongoing interaction of persons and their environment. Renninger, Hidi and Krapp (1992) described the components of interest as individual and situational. The educational system in Nigeria since independent has created opportunity for individuals, beginning from elementary school to make judgment interest about his or her own future career. This model was developed by a Professor in University of Lagos presented at COREN Work shop in Abuja 2011. As it can be seen in the figure the choice of future career is open to every individual in Nigeria. It is now the responsibility of our government or leaders to open corridor of support and look at our economic passage to see that individual Nigerian is contributing their own quota and at the same time governments must consider the role play by VET seriously.)

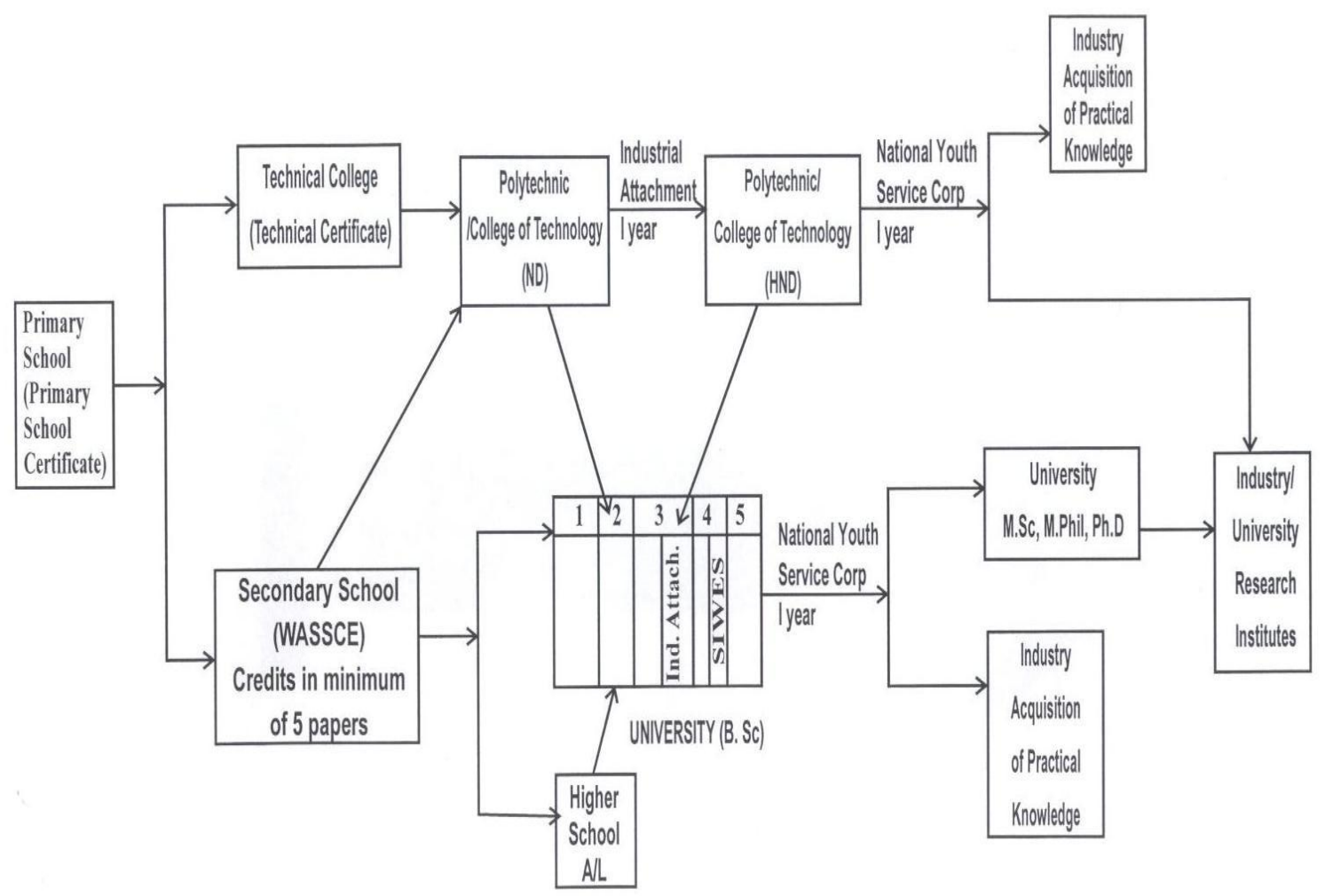

Figure 2 VET Admission procedures (COREN 2010)

Nigerian governments (Federal, State, Federal Territory and Local) must open these corridors down to develop our mind and our soul and must not make an attempt to kill our hope or take away everything we have hope for in this country.

\section{INSTITUTIONAL LEADERS AND MANAGERS}

Managers are compromisers, conservators, regulators and controllers who gain their selves - worth and identity by perpetuating existing system.

Leaders display personal and active attitude toward goals, they are innovative, risk takers and motivators who risk their self worth and identity by changing and improving existing system and organization. Tannenbaum and Schmidt (1973) describe various factors they believed that should influence manager's choice of leadership style. They went further to explain the difference between a transformation leader and a transaction leader. Similarly, James McGregor Burn (2003), a political historian describes in his book titled "Leadership" the difference between transformation leader and transaction leader. These authors described transformation leader as one who changes the course of action and events and transaction leader as one who makes the existing courses of action work better.

Furthermore, Mosby Burns, J.M. (2003) described the difference between visionary and non visionary leader. He indicated that visionary leader articulates philosophy, makes informal contact with employees' at all level, project a receptive supporting image and pays attention to strength and talks about future business goals. A non - visionary leader solves daily problems, meets formally worth subordinates, maintain aloof rational image, pays attention to weakness and talk about current business activities. 
Warren Bunnies, a professor of management at USC shows in his book called "Leaders" that manager's do things right while leaders do the right thing.

Over a decade, many academic researchers and thinkers in Nigeria have been battling over the problem of leadership in Nigeria. Many Nigerians have seen this as a problem that has refused to go away. We grew up under this problem and many of us are fighting to differentiate right from wrong. What will happen if our children grow up under this problem and repeat the same journey? These groups of intellectuals are now calling for considerable leadership and less management. We do understand the natural tension between managers and leaders. We need to resolve this problem as fast possible. The author suggests that managers should not wrap themselves up in bureaucratic red tape and at the same time leaders should value the role of effective system, structure and size. If we can bring this dichotomy together then, in reality we can integrate all principles of leadership and management by blending both innovation and stability and order and flexibility.

Nigerian governments need to differentiate theoretical education from practical education. In addition, it is important that Stakeholders understand the distinction between theoretical and practical education including the advantages and disadvantages, in light of this they would be ensure that both are brought together in managing our organizations and communities. It can be seen that advantages are greater than disadvantages; fairly it shows that we need stability plus agility, large plus small, changing and unchanging, constancy plus creativity, broad plus narrow, control plus empowerment, technology plus people - practicality plus integrity, overall, need good management and transformation and visionary leadership.

Overall, the author believes, it is important to understand the role of VET in Nigeria community specifically technical division. Our community expects colleges of technologies and polytechnics including advanced technical colleges to satisfy their needs and in broad sense to satisfy the needs of our industries both large and small.

\section{ROLES AND OBJECTIVES OF VET}

Vocational education and training specifically technical division are being constructed to fulfill a certain roles and objectives in Nigeria community or society. The significance of these roles and objectives are centered on the following:

- Primarily, to serve the needs of our industries, commerce, and community in manpower areas of managers, middle - managers, supervisors, technicians, skilled, semi - skilled and support personnel both male and female.

- To provide vocational and personal development programs commencing after school certificate or high school.

- To provide an alternative route to other part of tertiary sector of education system.

- To improve the community technical services.

- To improve access to vocational education and training through program offered in various modes, designed to meet the need of individual at different career stages.

- To encourage innovation in the development of alternative curriculum modes appropriate to different career paths, jobs and personal needs.

- Top develop approaches which effectively integrate educational and training aspects.

- To establish and maintain close involvement with industries and, in particular, to increase the level of direct involvement with individual company on education and training matters.

- To encourage all staff in technical division to assist students to gain an understanding of self and of others, to develop their individual talents and potentials and to effectively contribute to and live in a changing society or community.

- To encourage the use of non- college based instructional resources appropriate to particular learning requirements in order to complement those available through existing VET colleges (Technical division).

- To evaluate and prioritize, on a continuing basis VET (Technical division) activities in the light of federal and state objectives and available resources for vocational education, personal development and industrial training.

- To establish an understanding and commitment, amongst all staff to achieving the objectives to the VET enterprise. Technical objectives to enhance the overall relevance and quality courses and means of deliver them:

- To achieve the closet attainable relationship between programs of the study provided by the division and the education and training needs of the community.

- To improve the VET technical division capacity to deliver programs of study which meet the need of individual firm and organizations considered to be the key sector of the community and nation's economy.

- To increase the level of VET (Technical division) involvement in external groups responsible for resources projects, industrial development and investment in the community. 
- To increase the availability of studies information to and its effective use by divisional staff.

- To prioritize forward planning and developmental activities through a number of main study programs relate to overall technical division objectives and available resources.

- To ensure that course standards programs recognition and accreditation procedures are maintained and improve.

- To enhance curriculum research / development and teaching standards appropriate to different learning strategies.

- To review/ evaluate overall and individual study area policies and programs in the light of experience and progress.

\section{DEFINITION}

Vocational Education and Training can be defined as structures which are being set up to provide further education specifically technical education division sensitivity to changing economic and social circumstances.

\section{PUBLIC AWARENESS OF VET TECHNICAL DIVISION}

VET technical division is extremely diverse and complex, both in its course offering and its organizational structures. VET is generally promoted principally through a wide range of printed materials, giving basic information on course contents availability and locations. Within the technical education division, much of these materials are provided through divisional publication structured according to study area and through regular press advertisement.

\section{States}

However state colleges and universities center, provide printed publicity materials to promote their activities in their own states and officers responsible for special programs which are centrally coordinated also take the initiative in making available necessary information to enable public or nationwide to take the advantage of the opportunities the program offers. Private of independent VET also promote similar publicity materials.

It is likely that this will remain a major component part of VET public awareness activities many years to come and that the production of basic information materials will continue to increase or expand. In addition, the continuing requirement to update, the contents of existing publications, new initiatives particularly those designed to increase technical education, will or may need to be brought adequately to the attention of the public.

\section{Federal / State Efforts}

The concept of Federal / State efforts seems emerging from various references within white papers produced by VET committee and federal tertiary education commission.

In author's view, it appears to contain two required elements:

1. First, a judgment on the quality of state programs.

2. Second, a measurement of financial contribution of the state government to different areas of VET (Technical division )

As distinct elements both must be considered usefully and must not be confused. Another concern, this is very important to understand that federal VET is highly or better funded than traditional state owned VET. However, state must continue to take responsibility for the provision of education of the highest possible quality and ensuring that education funds are administered equitably as possible so that no sector of the community is disadvantaged.

\section{CONCLUSION}

In summary, I have written at length and commenting on different issues affecting vocational education and training institutions in Nigeria. I referred to different issues keeping pace with social and technical change and talked about the importance and value. I will now draw your attention to the comment of three distinguished Nigerians, before I continue with what I think.

According to S.T Oni, a professor of mathematics, the goal of a society is to achieve excellent performance in technical; and intellectual activities in building the society as a whole. Similarly, Prof. Sam Ale, the director - General National Mathematics Centre, highlighted the commitment of the centre to entire and rest of the world and described that the objectives of the centre in two languages:

1. To train and develop its members

2. To prepare Nigeria for a leading role in the area of technological advancement in the world. (see Federal University of Technology Akure : (Official Bulletin) 
In attempt to highlight this problem further Mr. Kupolokun, has commented that 80 percent of works in the oil and gas industry are carried out offshore. The industry is yet to meet the condition of creating jobs at home and developing skills that are directly contributing to community capacity building. (See Federal University of Technology Akure: official Bulletin).

Overall, the comments of these authors were not substantially different from each other. It shows that skill development in Nigeria is still below international standard. The overall depiction showed that Nigerian leaders are not economic managers and they are neither visionary nor transformation leaders.

To my knowledge, there is no leader in Nigeria to display personal and active attitude towards goals. Does it mean that there is no leader who is innovative, risk taker and motivator who can risk his or her selfworth and identity by changing and improving existing system and organization in Nigeria? I do not believe this; but I can see that there is a linkage between corruption and under developing Nigeria.

It seems that this particular problem is not going away; it may be we need to gather strength and bringing with it sweeping changes to Nigerian society and making a reality that Nigerians do truly live in global community.

We need to understands the wide spread youth unemployment, the reduction of the competiveness of Nigerian industries due to technological changes worldwide.

According to Morgan (1992), advanced technology policies and strategies are centered on greater flexibility and choice, the balance between the provision of broad education and training, the need of industries and skill occupation have created opportunities for individuals to pursue long life career. In support of this comment, Burke (1994) highlighted some of the problems associated with policies affecting VET. He went further to say that the significance of globalization for any consideration of skill formation issues is that when all other factors of production - natural resources, capital and new product technologies - are highly mobile, it is then highly skilled workforce becomes dominant source of comparable advantages to attract direct foreign investment due to availability of high skilled workforce in that particular country.

This is to show that Nigerians needs a highly competent flexible skills and competent workforce at home and to be able to compete offshore to attract foreign investors (example India and China).

As we can see vocation education and training institutions exercise a direct influence on national productivity level which largely determines the lining standard and a country's ability to complete in the global economy. Vocational education and training institutions support knowledge - driven economic growth strategies and poverty reduction by

- Training a qualified and adaptable labour force, inclusion high level scientists, professionals, technicians, teachers, in basic and secondary, future government civil servants and business leaders.

- Generating new knowledge.

- Building the capacity to access the existing stores of global knowledge and adapt that knowledge to local use.

Almost all vocational education and training institutions in Nigeria specifically technical division are unique in their ability to integrate and create synergy - among these three dimensions: Sustainable, transformation and growth are not possible without the capacity - building contribution of an innovative VET system. Access to VET can open better employment and income opportunities to under privileged students. The norms, values, attitudes, ethic and knowledge that VET can impact to students constitute the social capital necessary to construct health civil societies and socially cohesive cultures.

Overall, the paper has described and analyzed a wide range of issues and comments of relevant points relating to problems facing skill development in Nigeria.

\section{CONCLUDING COMMENTS}

This paper was designed to address the complex set of factors which should be considered when assessing the role and performance of VET in Nigeria. It seems likely that the role of VET is under rated by the new administration in Nigeria. However, this study concludes with the following suggestions;

1. Federal and State government to set up a committee to reassess Vet role and performance and justify their commitments to economic development in Nigeria.

2. Similarly, vocational education and training institutions council should send a letter to the authority requesting submission from both Federal and State Governments to outlining their plans for the future.

3. Set up a committee to examine the economic, social and political context and examine the major trends of significance.

4. Examines the main issue in the main circumstances over the role and status of VET in Nigeria.

5. Survey historical data, notes, the major trends and shift of emphasis and consider their significance for future planning.

6. Identify the significance current trend in curriculum development and focuses on the major areas in which increase allocation of resources is required.

7. Consider the future needs for staffing, equipments and capital resources. 
8. Comment on the progress made so far.

Finally, future development should be directed towards increasing the availability of recurrent education for people who are looking for the jobs and people who are already in the work force that need to keep abreast on new development related to their field or who are forced by some circumstances to retrain for a different occupation.

\section{REFERENCES}

[1] Abraham Zalenik (2008), Hedgehogs and Foxes: Character, Leadership, and Command in Organization Palgrave, Macmillan: New York.

[2] Abraham Zalenik (2009) Managers and Leaders: Are They Different? (HBR Classic), Pelgrave, Macmillan: New York.

[3] John P. Cotter (1999), On What Leaders Really Do (Harvard Business Review Book), Amazon.com, United Kingdom.

[4] Krapp. A., Hidi. S \& Renninger. K.A (1992) Interest Learning and development. In K.A. Renninger. S. Hidi. \& A. Krapp (Eds) The role of interest in learning and development.

[5] Krapp. A. \& Prenzel, M. (Eds). (19920 . Interesse, Lernen Leistung. Munster: Sacchendorff.

[6] Mosby Burns, J.M. (2003) Transforming leadership: A new Pursuit of Happiness. New York: Atlantic; Monthly Press.

[7] Warren, J. B (2005), True North: discover your Authentic Leadership; Network series. 